\title{
Reviews and syntheses: to the bottom of carbon processing at the seafloor
}

\author{
Jack J. Middelburg ${ }^{1, *}$ \\ ${ }^{1}$ Earth Sciences, Utrecht University, P.O. Box 80 021, 3508 TA Utrecht, the Netherlands \\ * Invited contribution by Jack J. Middelburg, recipient of the EGU Vladimir Vernadsky Medal 2017.
}

Correspondence: Jack J. Middelburg (j.b.m.middelburg@uu.nl)

Received: 24 August 2017 - Discussion started: 29 August 2017

Revised: 21 November 2017 - Accepted: 8 December 2017 - Published: 19 January 2018

\begin{abstract}
Organic carbon processing at the seafloor is studied by biogeochemists to quantify burial and respiration, by organic geochemists to elucidate compositional changes and by ecologists to follow carbon transfers within food webs. Here I review these disciplinary approaches and discuss where they agree and disagree. It will be shown that the biogeochemical approach (ignoring the identity of organisms) and the ecological approach (focussing on growth and biomass of organisms) are consistent on longer timescales. Secondary production by microbes and animals is identified to potentially impact the composition of sedimentary organic matter. Animals impact sediment organic carbon processing by microbes in multiple ways: by governing organic carbon supply to sediments, by aeration via bio-irrigation and by mixing labile organic matter to deeper layers. I will present an inverted microbial loop in which microbes profit from bioturbation rather than animals profiting from microbial processing of otherwise lost dissolved organic resources. Sediments devoid of fauna therefore function differently and are less efficient in processing organic matter with the consequence that more organic matter is buried and transferred from Vernadsky's biosphere to the geosphere.
\end{abstract}

\section{Introduction}

The seawater-sediment interface represents one of the largest interfaces on Earth and our knowledge of processes at and fluxes through this dynamic and understudied interface is rather limited. This interface extends a few centimeters to decimeters upwards into the water column, i.e., benthic boundary layer (Boudreau and Jørgensen, 1992), as well as a few centimeters to decimeters into the sediments, i.e., the bioturbated, active surface layer (Berner, 1980; Meysman et al., 2006; Aller, 2013). It serves as a habitat for organisms, governs the partitioning of material being buried or recycled and acts as a filter for the paleorecord (Rhoads, 1974). Processes in the surface sediment layer determine whether remains from organisms (organic matter, biogenic silica) are recycled within the biosphere (short-term cycle) or transferred to the geosphere (long-term cycle) and as such it functions as a key interface in the Earth system.

This pivotal role of the seafloor in processing deposited material has been studied by scientists from various disciplines with their own interests, techniques and paradigms (Fig. 1). Marine geologists and paleoceanographers study sediments with the primary aim to extract information on past environmental conditions using down-core measurements of substances that have survived the processing at the seafloor (Burdige, 2006; Bender, 2013). Biogeochemists quantify the fate of material delivered, in particular how much of that is eventually buried or processed, and determine when and in what form the remaining part is recycled as key nutrients to sustain primary production in the water column (Berner, 1980; Aller, 1980, 2001, 2013; Soetaert et al., 2000). Organic geochemists investigate how organic matter delivered to the seafloor is degraded, transformed or preserved using changes in the composition at the molecular level (Hedges and Keil, 1995; Dauwe et al., 1999; Burdige, 2006; Bianchi and Canuel, 2011). Ecologists focus on the organisms, i.e., the actors consuming, producing and transporting the material deposited (Gage and Tyler, 1992; Gray and Elliot, 2009; Herman et al., 1999; Krumins et al., 2013). 


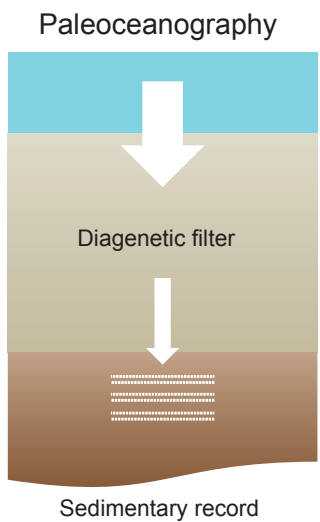

Sedimentary record
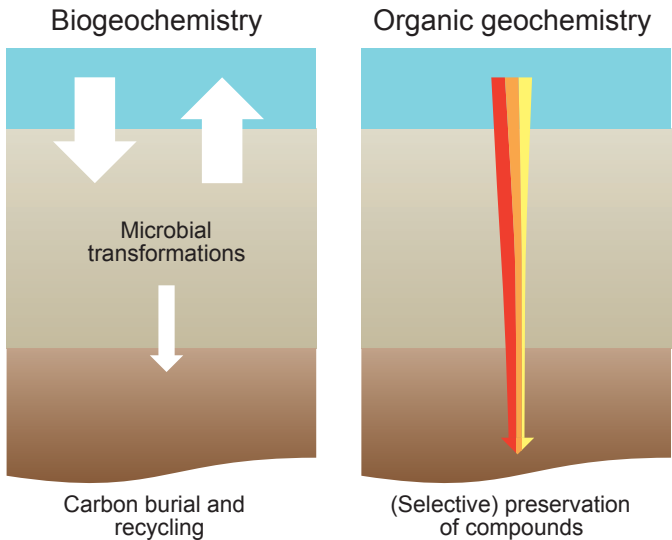

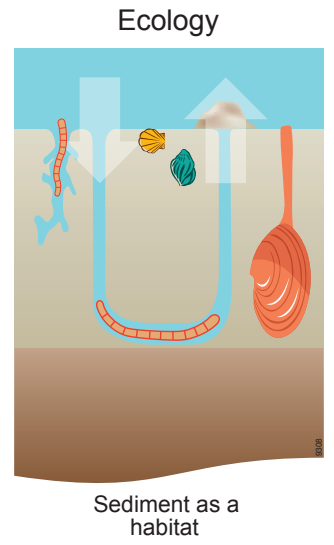

Figure 1. Different views on, approaches to and interests in carbon processing in marine sediments. Paleoceanographers focus on the sedimentary record, biogeochemists quantify carbon burial and recycling, organic geochemists study alteration of organic matter, and ecologists focus on carbon as food for organisms living in the sediment. The red-orange-yellow fractions of organic matter have a different lability.

Although these disciplines often study the same topic, e.g., organic matter delivered to the seafloor, they focus on different aspects and usually underappreciate or do not incorporate key concepts, findings and approaches from other disciplines. For example, ecologists and biogeochemists studying carbon flows at the seafloor normally ignore detailed molecular information available from organic geochemistry (Berner, 1980; Glud, 2008). Bioturbation, biological reworking of sediments (Meysman et al., 2006), is often ignored by paleoceanographers, and biogeochemists (Berner, 1980; Boudreau, 1997) have developed advanced transportreaction models in which the actors, the animals, mix the sediment but do so without consuming organic matter.

Here I present the existing views on organic carbon processing at the seafloor, discuss where they agree and disagree, and aim to arrive at an integrated view of carbon processing at the seafloor that is consistent with recent views within the organic geochemical, biogeochemical and ecological research communities. This overview is necessarily and admittedly incomplete but rather covers personal interests and presents new concepts on this topic. It is a concise version of the Vernadsky Medal Lecture presented at the 2017 EGU meeting.

\section{Biogeochemists focus on quantification of burial and mineralization}

Organic matter delivered to marine sediments is either mineralized and the metabolites (carbon dioxide and nutrients) accumulate in pore waters and exchange with the overlying water or buried through the steady accumulation of particles (Fig. 2). This biogeochemical view (Berner, 1980; Boudreau, 1997; Aller, 2013) is highly simplified but for that reason also quantitative and, I believe, instructive. The percentage of organic matter buried varies from less than $1 \%$ to a few tens of percent and is closely and positively related with total sediment accumulation rate (Canfield, 1989, 1994; Middelburg et al., 1993). Since sediment accumulation rates are high in vegetated, coastal, deltaic, shelf and ocean-margin settings, the majority of organic matter burial occurs there, with organic carbon burial in deep-sea sediments accounting for $<5 \%$ of the total buried matter (Berner, 1982; Duarte et al., 2005; Burdige, 2007). In the deep sea and other settings with low burial efficiency, almost all organic matter is degraded to inorganic carbon at rates that provide an excellent approximation for organic matter deposition (Jørgensen, 1982; Cai and Reimers, 1995; Glud, 2008). Organic matter degradation can be quantified via the consumption of oxygen, the production of dissolved inorganic carbon and through the use of pore-water data and diagenetic models (i.e., reaction-transport models for sediments). At steady state, sediment oxygen consumption provides an accurate measure for total sediment organic matter degradation, independent of whether organic matter is degraded aerobically (i.e., with oxygen) or anaerobically (with alternative electron acceptors such as nitrate, metal oxides and sulfate), because almost all reduced metabolites released (ammonium, manganese(II), iron(II), hydrogen sulfide and methane) are reoxidized (Jørgensen, 1977, 2006; Berner and Westrich, 1985; Aller and Rude, 1988; Soetaert et al., 1996; Boetius et al., 2000; Strous and Jetten, 2004; Raghoebarsing et al., 2006; Middelburg and Levin, 2009).

Biogeochemists have adopted a transport-reaction modeling approach to accurately quantify organic matter processing (Berner, 1980; Boudreau, 1997; Burdige, 2006). The basic premise of these diagenetic models is that both particles and solutes are subject to transport and reaction, making them distinct from, for instance, groundwater transportreaction models in which normally only solutes and gas 


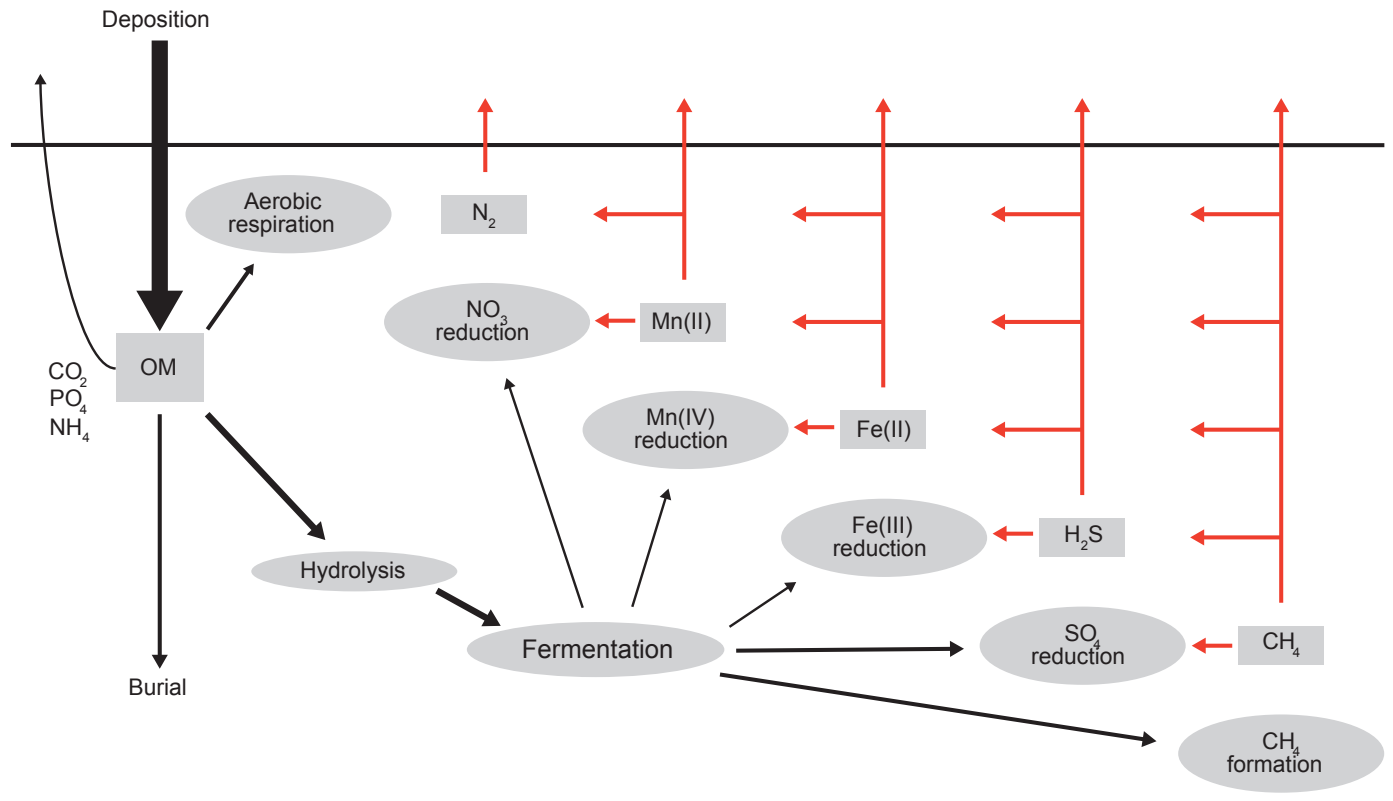

Figure 2. Conceptual model of organic matter (OM) degradation and reoxidation pathways (based on Jørgensen, 2006, and Middelburg and Levin, 2009). The red arrows reflect the fate of (energy-rich) substrates released during anaerobic mineralization.

phases are mobile (Lichtner, 1996; Appelo, 1996). Transport of solutes is due to molecular diffusion, pore-water advection and biologically mediated processes such as enhanced diffusion due to interstitial fauna (Aller and Aller, 1992) and bio-irrigation due to tube and burrow construction and flushing by macrofauna (Aller, 1980, 1984, 2001; Volkenborn et al., 2010, 2016; Kristensen et al., 2012). Particle transport is not only due to steady particle deposition but also due to sediment reworking by animals (bioturbation, Boudreau, 1997; Aller, 1994, 2013; Rice, 1986; Meysman et al., 2003, 2006, 2010). The reaction terms in these diagenetic models are normally limited to microbial and chemical reactions and are described using zero-, first- or second-order kinetic relationships or Monod- and/or Michaelis-Menten-type kinetics (Bouldin, 1968; Berner, 1980; Soetaert et al., 1996; Boudreau, 1997). There is a major inconsistency in the basic conceptual model underlying the (numerical) diagenetic models: animals dominate transport processes via pore-water irrigation and particle mixing, but without consuming any organic matter. This inconsistency has not received much attention because the ruling paradigm within the biogeochemical research community is that animals contribute very little to total carbon processing. Multiple recent studies involving use of ${ }^{13} \mathrm{C}$ as deliberate tracers show that this premise does not hold in the short term (days to weeks; Blair et al., 1996; Moodley et al., 2002, 2005a; Woulds et al., 2009, 2016). Moreover, detailed studies of oxygen consumption have revealed that animals contribute substantially to total sediment oxygen uptake: directly via their respiration as well as indirectly via particle and solute mixing (Glud, 2008). Neverthe- less, diagenetic models can very accurately reproduce most observations (Soetaert et al., 1996; Berg et al., 2003).

Diagenetic models combined with solid-phase and porewater depth profiles, sediment-water exchange fluxes, and rate measurement have resulted in a consistent picture of organic matter degradation pathways in marine sediments (Berner, 1980; Boudreau, 1997; Aller, 2013). These models can predict where, when and why organic matter oxidation occurs aerobically or involves nitrate, metal oxides or sulfate as oxidants (Rabouille and Gaillard, 2001; Boudreau, 1996; Soetaert et al., 1996; Middelburg et al., 1996; van Cappellen and Wang, 1996; Archer et al., 2002; Meysman et al., 2003; Berg et al., 2003). They also resolve the reoxidation of reduced products such as ammonium, manganese(II), iron(II), sulfide, and methane (Fig. 2) and as such define the scope for aerobic and anaerobic organisms, including the distribution and activity of chemoautotrophs (Middelburg, 2011). Despite these advances, diagenetic models cannot predict organic carbon burial rates, nor do they provide much insight into why organic matter is buried, or why it is either labile (reactive) or refractory. For this we need to have a detailed look at the organic geochemistry of sediment organic carbon.

\section{Organic geochemists focus on the composition of organic matter preserved}

Organic matter delivered to the seafloor is predominantly produced in the surface sunlit layer of the ocean (Fig. 3). This organic matter is rich in proteins, carbohydrates, and lipids and generally follows Redfield stoichiometry (Sterner 
(a)

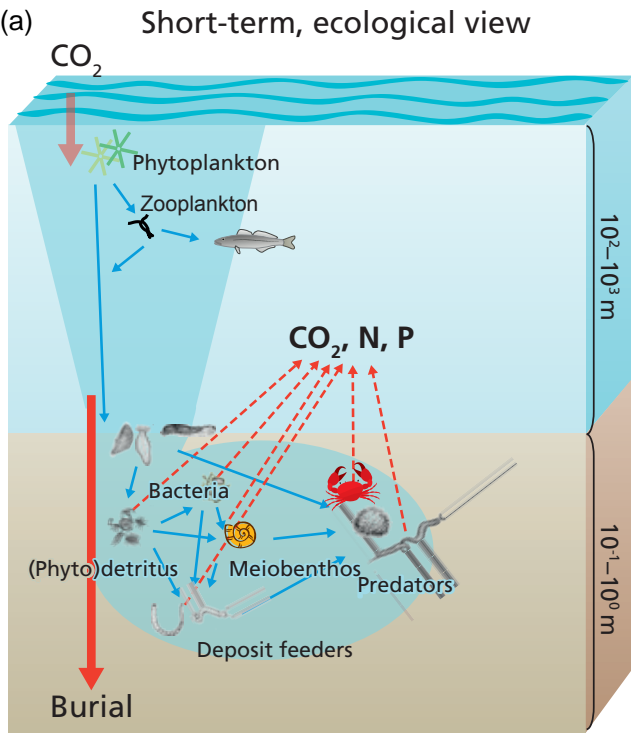

(b) Long-term, biogeochemical view

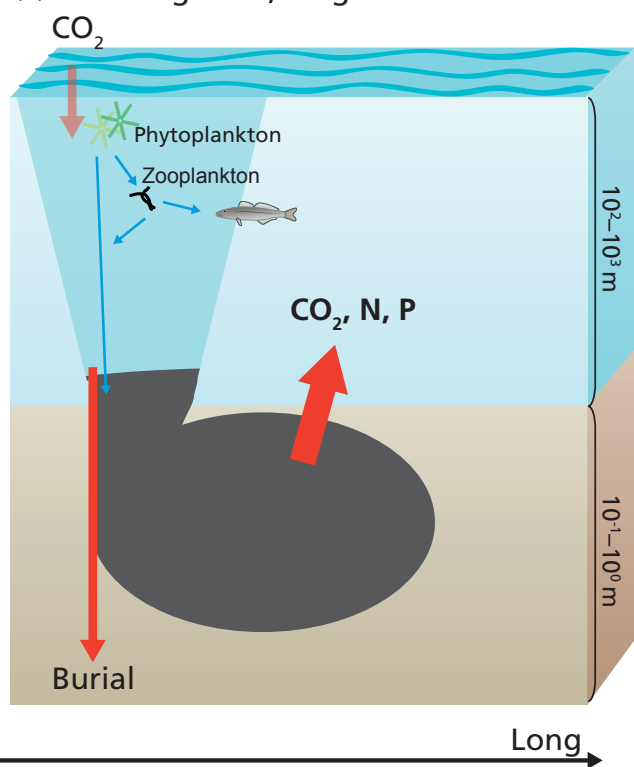

Time

Figure 3. Carbon processing in marine sediments in the short-term (a) and the long-term (b). Organic matter produced in the sunlit layer of the ocean and delivered to the sediments is either consumed by organisms or buried. The organic matter consumed by organisms is used to synthesize biomass or is metabolized to carbon dioxide and nutrients. In the long-term or at steady-state, i.e., the biomass of benthic organisms does not change, the benthic community can be considered a black box diverting organic matter into either metabolites or the geosphere (burial).

and Elser, 2002; Bianchi and Canuel, 2011). Organic matter processing leads to preferential degradation of the more labile components with the result that organic matter becomes less reactive (Jørgensen, 1979; Westrich and Berner, 1984; Middelburg, 1989; Arndt et al., 2013) and organic matter composition changes (Fig. 1; Wakeham et al., 1997; Dauwe et al., 1999; Lee et al., 2000). The proportion of organic matter that can be characterized molecularly decreases with progressive degradation, i.e., with water depth or depth downcore (Wakeham et al., 1997; Hedges et al., 2000; Middelburg et al., 1999; Nierop et al., 2017). This molecularly uncharacterizable material increases to more than $70 \%$ of the total in deep-sea sediment organic matter. The organic geochemical approach to studying organic matter processing is limited not only by our inabilities to characterize the majority of the sedimentary organic matter but also by the simple fact that the degraded fraction cannot be easily studied and we have to base our knowledge on the small fraction of extensively processed organic material remaining.

The changes in organic matter composition due to organic matter processing have been utilized to estimate the lability and digestibility or the refractory nature of organic matter with various proxies such as the ratio of chlorophyll to bulk organic matter, fraction of nitrogen present as amino acids, and the contribution of proteins and carbohydrates to total organic matter (Cowie et al., 1992; Dell'Anno et al., 2000; Danovaro et al., 2001; Koho et al., 2013). The amino-acid- based degradation index (Dauwe and Middelburg, 1998) is one of the most commonly used proxies to quantify the extent of degradation or the quality of the remaining particulate organic matter and is based on subtle changes in the amino acid composition due to organic matter processing (Dauwe et al., 1999; Keil et al., 2000).

The compositional changes have also been used to infer transformation of organic matter by bacteria (Cowie and Hedges, 1994; Dauwe et al., 1999; Grutters et al., 2001; Vandewiele et al., 2009; Lomstein et al., 2006, 2012), extent of degradation under oxic and anoxic conditions (Sinninghe Damsté et al., 2002; Huguet et al., 2008; Nierop et al., 2017), and the relative importance of bacteria and fauna for organic matter degradation (Sun et al., 1999; Woulds et al., 2012, 2014). Although some organic geochemical studies hint at the importance of secondary production (Hayes et al., 1989; Cowie and Hedges, 1994; Grutters et al., 2001; Lomstein et al., 2006, 2012), this aspect has received little attention in organic geochemistry; however, it is one of the main objectives within the ecological approach.

\section{Ecologists focus on the dynamics of organisms using organic matter}

Benthic communities are usually partitioned into different size classes (e.g., macrofauna, meiofauna and microbes; 
Gage and Tyler, 1992; Gray and Elliot, 2009; Herman et al., 1999), which are often studied by different research communities having distinct objectives, approaches and tools. Organic matter delivered to the seafloor fuels benthic food webs, i.e., it represents food for the animals and the energy substrate for heterotrophic microbes. Microbial ecologists study the growth of microbes on delivered organic matter (e.g., bacterial production) and subsequent microbial loss processes, including predation and viral lysis (Kemp, 1988; 1990; Danovaro et al., 2008, 2011, 2016). Microbial ecologists also study in detail the identities and activities or organisms involved in (an)aerobic respiration pathways and the reoxidation of reduced metabolites produced during anaerobic organic matter degradation (Canfield et al., 2005). Animal ecologists focus on the response of fauna to food delivery, the diet and growth of animals, and transfer of carbon up the food chain to top consumers (Krumins et al., 2013; Fig. 3). Interactions among food-web members are considered the key to understanding carbon flows (Pimm et al., 1991; van Oevelen et al., 2010).

During the last 2 decades, ${ }^{13} \mathrm{C}$-labeled phytodetritus addition experiments have been performed to identify the organisms involved in the immediate processing of organic matter delivered to the seafloor (Middelburg, 2014). These studies often covered all size classes (animals and microbes) and could show that respiration was the major fate of added phytodetritus and that all size classes directly profited from recently deposited organic matter (Blair et al., 1996; Moodley et al., 2002, 2005a; Woulds et al., 2007, 2009, 2016; Witte et al., 2003; Nomaki et al., 2005; Sweetman and Witte, 2008). In other words, heterotrophic microbes and small and big animals compete for the same food. Van Nugteren et al. (2009b) have shown that the spatial distribution of resources is a key factor governing the relative use of phytodetritus by bacteria vs. animals. Moreover, the relative share of organisms in the processing of organic matter was, in some systems and for some consumers, proportional to the biomass of the benthic size class, but not always (Moodley et al., 2005a; Woulds et al., 2009, 2016). For instance, foraminifera and amoebid protozoa sometimes contribute disproportionally to short-term carbon processing reflecting high turnover of an active community (Moodley et al., 2002; Woulds et al., 2007).

\section{Towards a synthesis}

The above discussion on conceptual views within different research disciplines highlights a few discrepancies and gaps in our knowledge. Secondary production by animals and microbes is often not included in the biogeochemical view that focuses on preservation versus mineralization. It is also largely absent from the organic geochemical literature. Consumption of organic matter is restricted to microbes in the biogeochemical view, while the non-fed animals move organic matter, microbes and particles around and enhance so- lute transfer by bio-irrigation activities. The consumption of organic matter eventually results in compositional changes of the organic matter remaining, but there is little information that the identity of the organism matters much. Whole ecosystem labeling experiments revealed direct flow from detritus to most benthic consumers and to the dissolved inorganic carbon pool, but these short-term experimental results cannot directly be compared to the long-term natural processing of deposited organic matter because long-term transfers within the food web and eventual carbon preservation cannot be resolved experimentally.

\subsection{On the consistency of food-web carbon processing and the biogeochemical burial-respiration partitioning}

Food-web models describe the exchange of matter (e.g., carbon or energy) among different compartments (organisms) within an ecosystem (Pimm et al., 1991; de Ruiter et al., 1995) and usually lump respiration losses (Cole et al., 2006; van Oevelen et al., 2010; Fig. 3a). Experimental studies using ${ }^{13} \mathrm{C}$-labeled phytodetritus as a tracer of sediment carbon processing showed that both animals and microbes can assimilate labile carbon directly and confirmed that respiration is the largest sink (Moodley et al., 2005a; Buhring et al., 2006; Andersson et al., 2008; Woulds et al., 2009, 2016). The biogeochemical budgeting approach basically distinguishes only between (refractory) carbon preserved and buried versus labile organic carbon that is respired to carbon dioxide (Aller, 2013; Fig. 3b). These ecological and biogeochemical concepts can be consistent depending on the timescale considered. On the timescale of days to months, deposited carbon is processed by the benthic organisms, a small part is assimilated and the majority is respired. On longer timescales and when considering steady-state conditions, i.e., constant faunal and microbial biomass, there is transfer from the detritus pool to the living biomass pool, but these secondary producers die and their remains are returned to the detritus pool for another cycle with the result that eventually all labile organic matter is respired.

\subsection{Secondary production and the formation of molecularly uncharacterizable organic matter}

The mere presence of living organisms in sediments clearly indicates that secondary production is omnipresent. Microbes usually dominate living biomass, but not always, and living biomass typically contributes a few percent to the standing stock of total organic carbon in coastal sediments (Herman et al., 1999). The importance of microbial biomass relative to total biomass increases with increasing water depth (Rex et al., 2006; Danovaro et al., 2014, 2015). Moreover, living biomass may contribute substantially to total carbon stocks in coarse-grained sandy sediments with low background organic carbon contents (Her- 


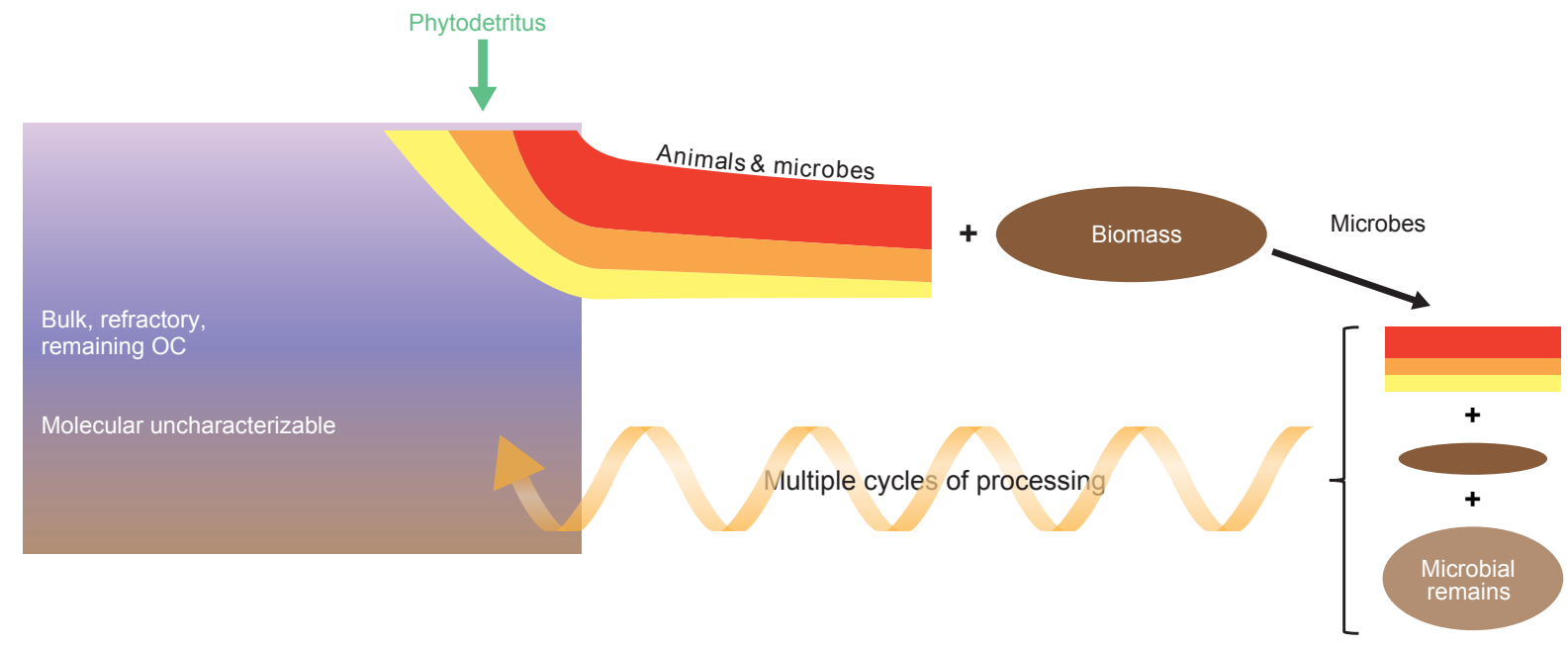

Figure 4. Conceptual diagram showing the relationships between molecular uncharacterizable organics, deposited phytodetritus and secondary production. Phytodetritus is degraded preferentially and new biomass is formed, which after death of the organisms is added to the pool of detritus and subject to degradation. Multiple cycles of organic matter processing eventually result in the formation of molecular uncharacterizable organic matter. The red-orange-yellow fractions of organic matter have a different lability.

man et al., 1999; Evrard et al., 2012). Various types of experimental evidence have shown that carbon flow through the living compartment is much higher than through the nonliving sediment organic matter pool. Short-term in situ experiments using ${ }^{13} \mathrm{C}$ - and/or ${ }^{15} \mathrm{~N}$-labeled organic matter (e.g., phytodetritus) revealed rapid incorporation of ${ }^{13} \mathrm{C} /{ }^{15} \mathrm{~N}$ in physically separated organisms (macro- and meiofauna and foraminifera) and microbes, the latter via incorporation of tracers in biomarkers specific for certain microbial groups (Middelburg et al., 2000; Boschker and Middelburg, 2002; Veuger et al., 2007; Oakes et al., 2012; Woulds et al., 2007, 2016) Similarly, ammonium isotope dilution studies have shown that net ammonification (ammonium release) is only a fraction of the total ammonium regeneration because a substantial part of the ammonium liberated is re-assimilated by the microbial community (Blackburn and Henriksen, 1983). Clearly the microbes and animals living in sediment assimilate carbon and synthesize new biomass (Veuger et al., 2012). How can this be reconciled with the biogeochemical and organic geochemical views in which organic matter is either preferentially degraded to carbon dioxide or selectively preserved (Figs. 1, 3). These two apparently inconsistent views are consistent if most of the newly produced organic matter is eventually degraded.

Detailed investigations of organic matter composition might in principle resolve this issue as microbial and animal processing of organic matter results in the formation of distinct compounds (Bradshaw et al., 1990; Sun et al., 1999; Thomas and Blair, 2002; Woulds et al., 2012, 2014). There are a few issues with this approach: (1) most sedimentary organic matter is molecularly uncharacterizable and the origin (imported from the water column vs. newly produced within the sediment) can thus not directly be investigated, (2) microbes living within (the guts) of animals may mask the animal signatures (Woulds et al., 2012, 2014) and (3) different analytical windows (amino acids vs. lipids) may result in different inferences. On the one hand, the accumulation of bacterially derived non-protein amino acids and peptidoglycan-derived D amino acids are clear signs that extensively modified organic matter contains a major fraction that is derived from (heterotrophic) bacteria (Cowie and Hedges, 1994; Dauwe et al., 1999; Grutters et al., 2001; Lomstein et al., 2006; Keil and Fogel, 2001; Keil et al., 2000). Using fatty acids, Gong and Hollander (1997) also identified a substantial microbial contribution to sedimentary organic matter. On the other hand, using a combined lipidisotope approach, Hartgers et al. (1994) reported only a minor contribution of bacteria to sedimentary organic carbon pools.

Secondary production has potentially major consequences for the interpretation of sedimentary records. If microbial reworking of deposited organic matter represents a major carbon flow and part of the material is preserved, then one would expect that bulk organic matter properties such as $\mathrm{C}, \mathrm{N}$, and $\mathrm{P}$ elemental ratios and nitrogen and carbon isotopes would reflect this. Degradation of organic matter initially results in the preferential release of nitrogen and phosphorus relative to carbon. Microbes normally have lower $\mathrm{C}: \mathrm{N}$ ratios than their substrate (Sterner and Elser, 2002), implying that secondary production and accumulation of microbially derived organic matter should eventually result in a net decrease in sediment $\mathrm{C}: \mathrm{N}$ ratios (Müller, 1977). In contrast, the $\mathrm{C}: \mathrm{P}$ ratio of heterotrophic microbes is rather variable because $\mathrm{P}$ demands depend on the growth rate (Sterner and Elser, 2002) and slowly 


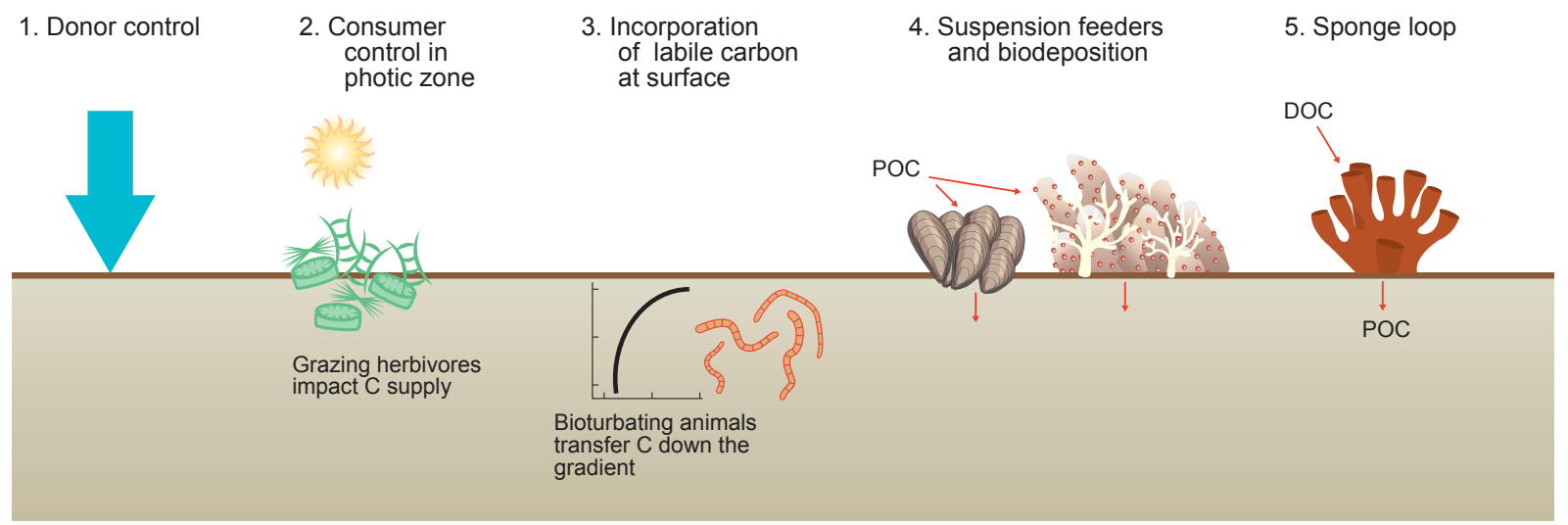

Figure 5. Organic matter supply to sediments. (1) The traditional view of organic matter settling passively from the water column (donor control). (2) Sediments in the photic zone are inhabited by benthic microalgae that produce new organic matter in situ and grazing animals can impact the growth of these primary producers. (3) Bioturbating animals transfer labile carbon from the sediment surface layer to deeper layers in the sediments. (Vertical axis is depth; horizontal axis is concentration.) (4) Suspension-feeding organisms enhance the transfer of suspended particulate matter from the water column to the sediments (biodeposition). (5) Sponge consume dissolved organic carbon and produce cellular debris that can be consumed by benthic organisms (i.e., the sponge loop).

growing benthic microbes may have high $\mathrm{C}: \mathrm{P}$ ratios (Steenbergh et al., 2013). Moreover, microbial P storage also depends on redox conditions with the consequences that sedimentary $\mathrm{C}: \mathrm{P}$ ratios are highly variable (Algeo and Ingall, 2007). Sediment $\delta^{15} \mathrm{~N}$ values often show a post-depositional shift towards heavier values in alternating oxic-anoxic settings (Moodley et al., 2005b). Such a shift is to be expected because regenerated ammonium is either transformed into nitrite-nitrate (nitrification) or re-assimilated by the microbial community. During oxic conditions nitrification occurs with preference for ${ }^{14} \mathrm{~N}$, and the remaining ammonium available for re-assimilation by microbes will be relatively rich in ${ }^{15} \mathrm{~N}$, while during anoxic conditions oxidation of ammonium is less important or absent, and the ammonium re-assimilated will have $\delta^{15} \mathrm{~N}$ values similar to that regenerated. Secondary production within sediment may also impact the interpretation of bulk stable carbon isotope records (Hayes et al., 1998) and paleorecords of microbial biomarkers (Schouten et al., 2010).

To reconcile the strong experimental evidence for preferential degradation (Middelburg, 1989), selective preservation (Tegelaar et al., 1989) and formation of new compounds by secondary producers (Lomstein et al., 2012; Braun et al., 2017), I present a new integral concept (Fig. 4). Phytodetritus delivered to sediments is preferentially degraded with the result that new biomass is formed and that some compounds are selectively preserved. The newly formed biomass is, after death of the organism, added to the pool of degraded detritus and subject to further microbial processing. After multiple cycles of processing by benthic heterotrophs most of the remaining organic matter becomes molecularly uncharacterizable. This conceptual model is consistent with the ruling paradigms of preferential degradation and selective preserva- tion as well as with the occurrence of secondary production and formation of molecular uncharacterizable organic matter, but the next step is to quantify this conceptual view. One approach would be to use proxies for organic matter degradation state such as fraction of total nitrogen present as amino acid, non-protein amino acid accumulation and the degradation index (Cowie and Hedges, 1994; Dauwe and Middelburg, 1998; Dauwe et al., 1999). Lomstein et al. (2012) and Braun et al. (2017) used amino acid racemization to quantify turnover of living microbial biomass as well as of bacterially derived organic matter (necromass) in the deep biosphere. Veuger et al. (2012) executed a ${ }^{13} \mathrm{C} /{ }^{15} \mathrm{~N}$ tracer experiment and followed the isotope labels into carbohydrates, amino acids, and lipids and basically showed that most of the deliberately added heavy isotopes were recovered from the molecularly uncharacterizable pool within a few weeks and remained in that pool till the end of the experiment ( $>1$ year). Their study provided direct evidence for rapid formation of new microbial biomass and subsequent transfer of microbial biomass to the pool of molecularly uncharacterizable organic matter. Moreover, the efficient retention of label was indicative of recycling of molecules (or parts thereof) by microbes rather than de novo synthesis, consistent with findings for archaeal lipids in marine sediments (Takano et al., 2010; Lipsewers et al., 2018) and bacteria in soils (Dippold and Kuzyakov, 2016).

\subsection{Animals and carbon supply to sediments}

Marine sediments are often considered donor-controlled systems, i.e., organic matter is delivered via settling of organic matter produced in the sunlit upper part of the ocean (Fig. 3) and the consuming sediment communities have no control 
on its carbon delivery (Fig. 5). It is only on the timescale of ocean bottom-water renewal (100-1000 years) that nutrients regenerated by benthic organisms may impact primary producers in the sunlit upper part of the ocean (Soetaert et al., 2000). This is obviously different for sediments in the photic zone that make up about one-third of the coastal ocean (Gattuso et al., 1996) because animals can directly graze and consume the benthic primary producers at the sediment surface (Middelburg et al., 2000; Evrard et al., 2010, 2012; Oakes et al., 2012; Fig. 5). Donor and consumer controlled food webs have intrinsically different dynamics.

Animals living in sediments below the photic zone can in multiple ways impact carbon processing within marine sediments (Fig. 5). Deposit-feeding animals mix particles (and thus particulate organic carbon) as a consequence of their activities. In the case of constant organic carbon delivery (donor control), bioturbation stimulates organic carbon processing at depth (Herman et al., 1999). In coastal systems, organic matter delivery is more complex because of multiple deposition-resuspension events and lateral transport pathways. Rice and Rhoads (1989) showed that in this case (with a constant organic carbon concentration in the top layer) more sediment reworking will increase the organic matter flux into the sediment. Moreover, organic carbon gradients with depth are steeper for high-quality than low-quality material and particle mixing thus results in transfer of high-quality organic matter to (micro)organisms living at depth. Animals living in permeable sediment can via surface sediment topography (bio-roughness) induce pore-water flows, resulting in the trapping of phytoplankton (Huettel et al., 2014).

Tropical and cold-water corals, coastal and deep-sea sponges, suspension-feeding bivalves, and other marine forest communities utilize particulate organic matter suspended in the water (Herman et al., 1999; Roberts et al., 2006; Rossi et al., 2017). This organic carbon is used for maintenance respiration and growth, but part is excreted as feces or pseudofeces and then becomes available for consumers in the sediments. This can result in local hotspots of biodiversity and microbial activity in the sediments (Herman et al., 1999; Gutierrez et al., 2003; Cathalot et al., 2015). Moreover, the physical structures built by these ecosystem engineers impact hydrodynamics with consequences for local and distant carbon deposition rates. Soetaert et al. (2016) reported elevated carbon deposition to ocean margin sediments due to cold-water corals reefs at very large distances.

Some invertebrates have the capability to take up dissolved organic carbon and, in particular, sponges can assimilate substantial quantities and transform it into biomass (de Goeij et al., 2013; Fiore et al., 2017; Hoer et al., 2018). This sponge tissue and in particular its detritus can be consumed by benthic organisms. This sponge loop (de Goeij et al., 2013; Rix et al., 2016) is another example of how animals can manipulate the transfer of organic carbon from the water column to the sediments (Fig. 5). (a)

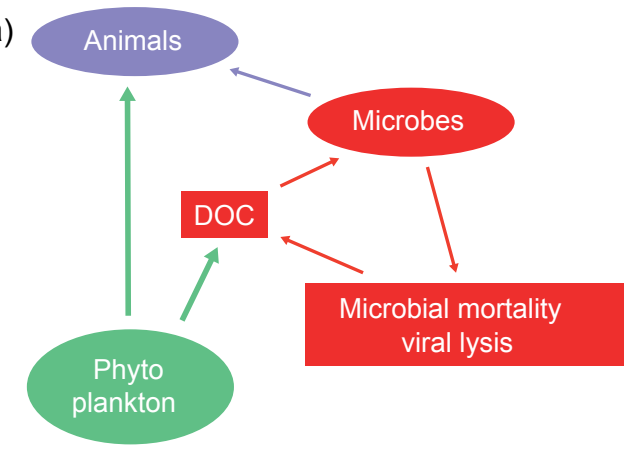

(b)

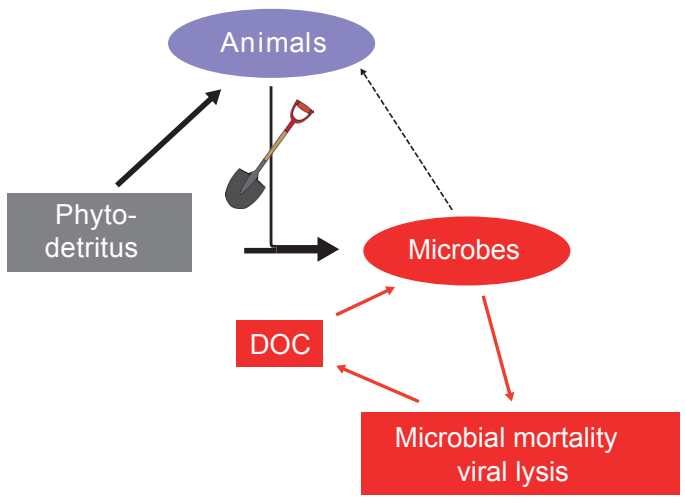

Figure 6. The microbial (a) and inverted microbial (b) loops. In the water column dissolved organic carbon derived from phytoplankton, zooplankton or microbes (via viral loop) is consumed by heterotrophic microbes, which in turn are consumed by protists and small animals, with the consequence that carbon flowing through dissolved organic carbon pools can eventually be used by larger animals (microbial loop). In sediments, the dissolved organic carbon (from viral lysis and other sources) is also consumed by heterotrophic microbes but this carbon is inefficiently transferred to animals. The engineering activities of animals are key in delivering labile organic matter (phytodetritus) to microbes living in the subsurface (inverted microbial loop).

\subsection{Animal stimulation of microbes: an inverted microbial loop?}

The microbial loop is a key concept in ocean biogeochemistry (Pomeroy, 1974; Azam et al., 1983). Dissolved organic matter released by phytoplankton, zooplankton, or viral lysis of bacteria, archaea and algae is consumed by heterotrophic microbes. These heterotrophs are in turn consumed by flagellates, ciliates and other small consumers that are predated upon by zooplankton (Azam et al., 1983; Jumars et al., 1989). Energy shunted into the large, heterogeneous dissolved organic matter pool is in this way made available again for animals (Fig. 6).

After discovery of this loop in the surface ocean water, research has been executed to identify and quantify it in sediments (Kemp, 1988, 1990). This required substantial invest- 
ment in developing new methods: these studies basically revealed that predation on sedimentary bacteria was not that important (Kemp, 1990; Hondeveld et al., 1992; Hamels et al., 2001; Guilini et al., 2009). Van Oevelen et al. (2006) conducted a detailed study on the fate of bacterial production using in situ ${ }^{13} \mathrm{C}$ labeling of bacteria. They observed that $8 \%$ was lost by physical processes, $27 \%$ was consumed by animal predation and bacterial mortality accounted for $65 \%$. Viruses are the most important loss term for sedimentary microbes (Danovaro et al., 2009, 2011, 2016) and the viral lysis products (dissolved organic matter) are consumed by microbes. This results in a dissolved organic carbon-microbes cycle (Fig. 6). This benthic microbial cycle represents a dead end in terms of food web topology because there is little transfer to higher trophic levels and most carbon is eventually respired as needed for mass-balance closure in the long term (Fig. 3).

In fact, the benthic microbial cycle represents more of an inverted microbial loop: rather than animals profiting from the microbial loop sensu Azam et al. (1983), it appears that benthic microbes profit from animals mixing labile organic matter downwards into the sediments (Fig. 6). Labile organic matter delivered to the sediment surface is mixed by animals inhabiting the sediments (Fig. 5). The transfer of highquality organic matter to deeper sediment layers may prime sediment microbial communities and in this way stimulate degradation of indigenous organic matter (Canfield, 1994; van Nugteren et al., 2009a, Bianchi, 2011; Hannadis and Aller, 2017). Moreover, tube construction and ventilation by animals brings dissolved oxygen to deeper sediment layers and will in this way stimulate organic matter mineralization (Canfield, 1994; Kristensen et al., 1995; Dauwe et al., 2001). Bio-irrigation activities may be intermittent (Volkenborn et al., 2016) and cause oscillations in oxygen availability that stimulate organic matter degradation (Aller and Aller, 1998). This inverted microbial loop is a prime example of how animals as ecosystem engineers impact sediment carbon processing (Meysman et al., 2006).

\subsection{Imagine a world without animals}

An ocean floor inhabited solely by microbes and without animals was likely the reference state during the first 4 billion of years of Earth's history (Canfield, 2014; Lenton and Watson, 2011). Moreover, in modern systems with anoxic bottom waters benthic animals are absent (Rhoads and Morse, 1971; Diaz and Rosenberg, 1995, 2008; Levin, 2003; Levin et al., 2009). In these systems, organic matter degradation pathways are different not only because of a lack of oxygen and use of alternative electron acceptors, but also because bio-irrigation and sediment reworking are absent (Aller and Aller, 1998; Levin et al., 2009; Middelburg and Levin, 2009). Consequently, microbe-fauna interactions (enhanced carbon delivery, Fig. 5; animal stimulation of microbes, Fig. 6) are impeded.
While organic matter mineralization in the presence of oxygen may be more efficient than in anoxic environments (Canfield, 1994; Kristensen et al., 1995; Dauwe et al., 2001), the lack of animal stimulation of microbes may also contribute to burying organic carbon more efficiently in sediments underlying anoxic bottom waters (Hartnett et al., 1998; Hartnett and Devol, 2003; Middelburg and Levin, 2009; Jessen et al., 2017). Moreover, the organic matter buried in hypoxic and anoxic settings is usually less degraded (Cowie, 2005, Cowie et al., 2009; Vandewiele et al., 2009; Koho et al., 2013; Jessen et al., 2017). This presence of animals and all their interactions with organic matter and microbes has consequences for organic carbon processing in marine sediments and thus the global carbon cycle. It is obvious for any terrestrial microbiologist that a world with trees and other macrophytes would be different than one without. Moreover, biological oceanographers and limnologists agree that zooplankton and other metazoan consumers contribute to biogeochemical cycles (Vanni, 2002; Vanni and McIntyre, 2016), and I hope that colleagues studying marine sediments are aware that "bio-" in sediment biogeochemistry is more than just microbiology.

Data availability. No data sets were used in this article.

Competing interests. The author declares that he has no conflict of interest.

Acknowledgements. This paper presents my acceptance lecture for the Vladimir Ivanovich Vernadsky Medal 2017 of the European Geosciences Union. I thank the colleagues that nominated me for this award and the many colleagues, students and postdoctoral fellows with whom I have had the pleasure to interact and collaborate over the years. In particular, the late Carlo Heip, who was instrumental in obtaining more realistic biology for my biogeochemistry, as well as my long-term collaborators in modeling benthic ecosystems (Karline Soetaert, Peter Herman, Filip Meysman and Bernie Boudreau), in food-web studies (Dick van Oevelen, Leon Moodley), in organic geochemistry (Jaap Sinnighe Damsté and Stefan Schouten) and in coastal biogeochemistry (Jean-Pierre Gattuso and Carlos Duarte). Ton Marcus is thanked for graphic support. Don Canfield, Roberto Danovaro and the one anonymous referee are thanked for constructive feedback. This is a contribution to the Netherlands Earth System Science Centre supported by the Dutch Ministry of Education and Science.

Edited by: Tina Treude

Reviewed by: Donald E. Canfield, Roberto Danovaro, and one anonymous referee 


\section{References}

Algeo, T. J. and Ingall, E.: Sedimentary $\mathrm{C}_{\mathrm{org}}: \mathrm{P}$ ratios, paleocean ventilation, and Phanerzoic atmospheric $\mathrm{pO}_{2}$, Geochim. Cosmochim. Ac., 256, 130-155, 2007.

Aller, R. C.: Quantifying solute distributions in the bioturbated zone of marine sediments by defining an average micro environment, Geochim. Cosmochim. Ac., 44, 1955-1965, 1980.

Aller, R. C.: The importance of relict burrow structures and burrow irrigation in controlling sedimentary solute distributions, Geochim. Cosmochim. Ac., 48, 1929-1934, 1984.

Aller, R. C.: Bioturbation and remineralization of sedimentary organic matter - Effects of redox oscillation, Chem. Geol., 114, 331-345, 1994.

Aller, R. C.: Transport and reactions in the bioirrigated zone, in: The benthic boundary layer: transport processes and biogeochemistry, edited by: Boudreau, B. P. and Jørgensen, B. B., 269-301, 2001.

Aller, R. C. and Rude, P. D.: Complete oxidation of solid-phase sulphides by manganese and bacteria in anoxic marine sediments, Geochim. Cosmochim. Ac., 52, 751-765, 1988.

Aller, R. C. and Aller, J. Y.: Meiofauna and solute exchange in marine muds, Limnol. Oceanogr., 37, 1018-1033, 1992.

Aller, R. C. and Aller, J. Y.: The effect of biogenic irrigation intensity and solute exchange on diagenetic reaction rates in marine sediments, J. Mar. Res., 56, 905-936, 1998.

Aller, R. C.: Sedimentary Diagenesis, Depositional Environments, and Benthic Fluxes Treatise on Geochemistry, 2nd Edn., 8, 29333, 2013.

Andersson, J. H., Woulds, C., Schwartz, M., Cowie, G. L., Levin, L. A., Soetaert, K., and Middelburg, J. J.: Short-term fate of phytodetritus in sediments across the Arabian Sea Oxygen Minimum Zone, Biogeosciences, 5, 43-53, https://doi.org/10.5194/bg-543-2008, 2008.

Appelo, C. A. J.: Multicomponent ion exchange and chromatography in natural systems, Rev. Mineral., 34, 193-228, 1996.

Archer, D., Morford, J. L., and Emerson, S.: A model of suboxic diagenesis suitable for automatic tuning and gridded global domains, Global Biogeochem. Cy., 16, https://doi.org/10.1029/2000BG001288, 2002.

Arndt, S., Jorgensen, B. B., LaRowe, D., Middelburg, J. J., Pancost, R., and Regnier, P.: Quantification of organic matter degradation in marine sediments: A synthesis and review, Earth-Sci. Rev., 123, 53-86, https://doi.org/10.1016/j.earscirev.2013.02.008, 2013.

Azam, F., Fenchel, T., Field, J. G., Gray, J. S., Meyer-Reil, L. A., and Thingstad, F.: The ecological role of water-column microbes in the sea, Mar. Ecol.-Prog. Ser., 10, 257-263, 1983.

Bender, M. L.: Paleoclimate, Princeton University Press, 2013.

Berg, P., Rysgaard, S., and Thamdrup, B.: Dynamic modeling of early diagenesis and nutrient cycling, A case study in an Arctic marine sediment, Am. J. Sci., 303, 905-955, 2003.

Berner, R. A.: Early diagenesis: A theoretical approach, Princeton University Press, 1980.

Berner, R. A.: Burial of organic carbon and pyritic sulphur in the modern ocean: Its geochemical and environmental significance, Am. J. Sci., 282, 451-473, 1982.

Berner, R. A. and Westrich, J. T.: Bioturbation and the early diagenesis of carbon and sulphur, Am. J. Sci., 285, 193-206, 1985.
Bianchi, T. S.: The role of terrestrially derived organic carbon in the coastal ocean: a changing paradigm and the priming effect, P. Natl. Acad. Sci. USA, 108, 19473-19481, https://doi.org/10.1073/pnas.1017982108, 2011.

Bianchi, T. S. and Canuel, E. A.: Chemical biomarkers in aquatic ecosystems, Princeton University Press, 2011.

Blackburn, T. H. and Henriksen, K.: Nitrogen cycling in different types of sediments from Danish waters, Limnol. Oceanogr., 28, 477-493, 1983.

Blair, N. E., Levin, L. A., DeMaster, D. J., and Plaia, G.: The shortterm fate of fresh algal carbon in continental slope sediments, Limnol. Oceanogr., 41, 1208-1219, 1996.

Boetius, A., Ravenschlag, K., Schubert, C. J., Rickert, D., Widdel, F., Gieseke, A., Amann, R., Jorgensen, B. B., Witte, U., and Pfannkuche, O.: A marine microbial consortium apparently mediating anaerobic oxidation of methane, Nature, 407, 623-626, 2000.

Boschker, H. T. S. and Middelburg, J. J.: Stable isotopes and biomarkers in microbial ecology, FEMS Microbiol. Ecol., 40, 85-95, https://doi.org/10.1111/j.1574-6941.2002.tb00940.x, 2002.

Bouldin, D. R.: Models for describing diffusion of oxygen and other mobile constituents across mud-water interface, J. Ecol., 56, 7787, 1968.

Boudreau, B. P.: A method-of-lines code for carbon and nutrient diagenesis in aquatic sediments, Comput. Geosci., 22, 479-496, https://doi.org/10.1016/0098-3004(95)00115-8, 1996.

Boudreau, B. P.: Diagenetic models and their implementation, Modelling transport and reactions in aquatic sediments, SpringerVerlag, Berlin, Germany, 414 pp., 1997.

Boudreau, B. P. and Jorgensen, B. B.: The Benthic Boundary Layer: Transport Processes and Biogeochemistry, edited by: Boudreau, B. P. and Jorgensen, B. B., Oxford University Press, 1st Edn., 2001.

Bradshaw, S. A., O'hara, S. C. M., Corner, E. D. S., and Eglinton, G.: Changes in lipids during simulated herbivorous feeding by the marine crustacean Neomysis integer, J. Mar. Biol. Assoc. UK, 70, 225-243, 1990.

Braun, S., Mhatre, S. S., Jaussi, M., Roy, H., Kjeldsen, K. U., Pearce, C., Seidenkrantz, M.-S., Jorgensen, B. B., and Lomstein, B. A.: Microbial turnover in the deep seabed studied by amino acid racemization modelling, Sci. Rep., 7, 5680, https://doi.org/10.1038/s41598-017-05972-z, 2017.

Buhring, S. I., Lampadariou, N., Moodley, L., Tselepides, A., and Witte, U.: Benthic microbial and whole-community responses to different amounts of ${ }^{13} \mathrm{C}$-enriched algae: In situ experiments in the deep Cretan Sea (Eastern Mediterranean), Limnol. Oceanogr., 51, 157-165, 2006.

Burdige, D. J.: Preservation of organic matter in marine sediments: controls, mechanisms, and an imbalance in sediment organic carbon budgets?, Chem. Rev., 107, 467-485, https://doi.org/10.1002/chin.200720266, 2007.

Burdige, D.: Geochemistry of Marine Sediments, Princeton University Press, 2006.

Cai, W. J. and Reimers, C. E.: Benthic oxygen flux, bottom water oxygen concentration and core top organic carbon content in the deep northeast Pacific Ocean, Deep-Sea Res. Pt. I, 42, 1681$1699,1995$. 
Canfield, D. E.: Sulphate reduction and oxic respiration in marine sediments - Implications for organic carbon preservation in euxinic environments, Deep-Sea Res. Pt. I, 36, 121-138, 1989.

Canfield, D. E.: Factors Influencing organic carbon preservation in marine sediments, Chem. Geol., 114, 315-239, 1994.

Canfield, D. E.: Oxygen, a four billion year history, Princeton University Press, 2014.

Canfield, D. E., Thamdrup, B., and Kristensen, E.: Aquatic geomicrobiology, in: Advances in Marine Biology, edited by: Southward, A. J., Tyler, P. A., Young, C. M., and Fuiman, L. A., Elsevier Academic Press, Amsterdam, 48, 640 pp., 2005.

Cathalot, C., Van Oevelen, D., Cox, T. J. S., Kutti, T., Lavaleye, M., Duineveld, G., and Meysman, F. J. R.: Cold-water coral reefs and adjacent sponge grounds: Hotspots of benthic respiration and organic carbon cycling in the deep sea, Front. Mar. Sci., 2, 37, https://doi.org/10.3389/fmars.2015.00037, 2015.

Cole, J. J., Carpenter, S. R., Pace, M. L., Van de Bogert, M. C., Kitchell, J. L., and Hodgson, J. R.: Differential support of lake food webs by three types of terrestrial organic carbon, Ecol. Lett., 9, 558-568, https://doi.org/10.1111/j.1461-0248.2006.00898.x, 2006.

Cowie, G.: The biogeochemistry of Arabian Sea surficial sediments: A review of recent studies, Prog. Oceanogr., 65, 260-289, 2005.

Cowie, G. L. and Hedges, J. I.: Biochemical indicators of diagenetic alteration in natural organic-matter mixtures, Nature, 369, 304307, 1994.

Cowie, G. L, Mowbray S., Lewis M., Matheson H., and McKenzie R.: Carbon and nitrogen elemental and stable isotopic compositions of surficial sediments from the Pakistan margin of the Arabian Sea, Deep-Sea Res. Pt. II, 56, 271-282, 2009.

Cowie, G. L, Hedges J. I., and Calvert S. E.: Sources and relative reactivities of amino acids, neutral sugars, and lignin in an intermittent anoxic marine environment, Geochim. Cosmochim. Ac., 56, 1963-1978, 1992.

Danovaro, R., Dell'Anno, A., and Fabiano, M.: Bioavailability of organic matter in the sediments of the Porcupine Abyssal Plain, northeastern Atlantic, Mar. Ecol.-Prog. Ser., 220, 25-32, https://doi.org/10.3354/meps220025, 2001.

Danovaro, R., Dell'Anno, A., Corinaldesi, C., Magagnini, M., Noble, R., Tamburini, C., and Weinbauer, M.: Major viral impact on the functioning of benthic deep-sea ecosystems, Nature, 454, 1084-1088, 2008.

Danovaro, R., Corinaldesi, C., Dell' Anno, A., Fuhrman, J. A., Middelburg, J. J., Noble, R. T., and Suttle, C. A.: Marine viruses and global climate change, FEMS Microbiol. Rev., 35, 993-1034, 2011.

Danovaro, R., Snelgrove, P. V., and Tyler, P.: Challenging the paradigms of deep-sea ecology, Trends Ecol. Evol., 29, 465-475, 2014.

Danovaro, R., Corinaldesi, C., Rastelli, E., and Dell'Anno, A.: Towards a better quantitative assessment of the relevance of deepsea viruses, Bacteria and Archaea in the functioning of the ocean seafloor, Aquat. Microb. Ecol., 75, 81-90, 2015.

Danovaro, R., Dell'Anno, A., Corinaldesi, C., Rastelli, E., Cavicchioli, R., Krupovic, M., Noble, R. T., Nunoura, T., and Prangishvili, D.: Virus mediated archaeal hecatomb in the deep seafloor, Sci. Adv., 2, e1600492, https://doi.org/10.1126/sciadv.1600492, 2016.
Dauwe, B. and Middelburg, J. J.: Amino acids and hexosamines as indicators of organic matter degradation state in North Sea sediments, Limnol. Oceanogr., 43, 782-798, 1998.

Dauwe, B., Middelburg, J. J., Herman, P. M. J., and Heip, C. H. R.: Linking diagenetic alteration of amino acids and bulk organic matter reactivity, Limnol. Oceanogr., 44, 1809-1814, 1999.

Dauwe, B., Middelburg, J. J., and Herman, P. M. J.: Effect of oxygen on the degradability of organic matter in subtidal and intertidal sediments of the North Sea area, Mar. Ecol.-Prog. Ser., 215, 13$22,2001$.

de Goeij, J. M., van Oevelen, D., Vermeij, M. J. A., Osinga, R., Middelburg, J. J., de Goeij, A. F. P. M., and Admiraal, W.: Surviving in a Marine Desert: The Sponge Loop Retains Resources Within Coral Reefs, Science, 342, 108-110, https://doi.org/10.1126/science.1241981, 2013.

Dell'Anno, A., Fabiano, M., Mei, M. L., and Danovaro, R.: Enzymatically hydrolysed protein and carbohydrate pools in deep-sea sediments: estimates of the potentially bioavailable fraction and methodological considerations, Mar. Ecol.-Prog. Ser., 196, 1523, 2000 .

De Ruiter, P. C., Neutel, A.-M., and Moore, J. C.: Energetics, patterns of interaction strengths, and stability in real ecosystems, Science, 269, 1257-1260, 1995

Diaz, R. J. and Rosenberg, R.: Marine benthic hypoxia: A review of its ecological effects and the behavioural responses of benthic macrofauna, Oceanogr. Mar. Biol., 33, 245-303, 1995.

Diaz, R. J. and Rosenberg, R.: Spreading dead zones and consequences for marine ecosystems, Science, 321, 926-929, 2008.

Dippold, M. A. and Kuzyakov, Y.: Direct incorporation of fatty acids into microbial phospholipids in soils: position-specific labeling tells the story, Geochim. Cosmochim. Ac., 174, 211-221, 2016.

Duarte, C. M., Middelburg, J. J., and Caraco, N.: Major role of marine vegetation on the oceanic carbon cycle, Biogeosciences, 2, 1-8, https://doi.org/10.5194/bg-2-1-2005, 2005.

Evrard, V., Soetaert, K., Heip, C. H. R., Huettel, M., Xenopoulos, M. A., and Middelburg, J. J.: Carbon and nitrogen flows through the benthic food web of a photic subtidal sandy sediment, Mar. Ecol.-Prog. Ser., 416, 1-16, https://doi.org/10.3354/meps08770, 2010.

Evrard, V., Huettel, M., Cook, P. L. M., Soetaert, K., Heip, C. H. R., and Middelburg, J. J.: Importance of phytodetritus and microphytobenthos for heterotrophs in a shallow subtidal sandy sediment, Mar. Ecol.-Prog. Ser., 455, 13-31, https://doi.org/10.3354/meps09676, 2012.

Fiore, C. L., Freeman, C. J., and Kujawinski, E. B.: Sponge exhalent seawater contains a unique chemical profile of dissolved organic matter, Peer J., 5, e2870, https://doi.org/10.7717/peerj.2870, 2017

Gage, J. D. and Tyler, P. A.: Deep-sea biology: A natural history of organisms at the deep-sea floor, Cambridge University Press, 1991.

Gattuso, J.-P., Gentili, B., Duarte, C. M., Kleypas, J. A., Middelburg, J. J., and Antoine, D.: Light availability in the coastal ocean: impact on the distribution of benthic photosynthetic organisms and their contribution to primary production, Biogeosciences, 3, 489-513, https://doi.org/10.5194/bg-3-489-2006, 2006. 
Gray, J. S. and Elliot, M.: Ecology of marine sediments, 2nd Edn., Oxford University Press, 2009.

Gong, C. and Hollander, D.: Differential contribution of bacteria to sedimentary organic matter in oxic and anoxic environments, Santa Monica Basin, California, Geochim. Cosmochim. Ac., 26, 545-563, 1997.

Guilini, K., Van Oevelen, D., Soetaert, K., Middelburg, J. J., and Vanreusel, A.: Nutritional importance of benthic bacteria for deep-sea nematodes from the Arctic ice margin: Results of an isotope tracer experiment, Limnol. Oceanogr., 55, 1977-1989, 2010.

Glud, R. N.: Oxygen dynamics of marine sediments, Mar. Biol. Res., 4, 243-289, 2008.

Grutters, M., van Raaphorst, W., Epping, E., Helder, J., de Leeuw, J. W., Glavin, D. P., and Bada, J.: Preservation of amino acids from in situ-produced bacterial cell wall peptidoglycans in northeastern Atlantic continental margin sediments, Limnol. Oceanogr., 47, 1521-1524, 2002.

Gutierrez, J. L., Jones, C. G., Strayer, D. L., and Iribarne, O. O.: Mollusks as ecosystem engineers: the role of shell production in aquatic habitats, Oikos, 101, 79-90, 2003.

Hamels, I., Muylaert, K., Casteleyn, G., and Vyverman, W.: Uncoupling of bacterial production and flagellate grazing in aquatic sediments: a case study from an intertidal flat, Aquat. Microb. Ecol., 25, 31-42, 2001.

Hannides, A. K. and Aller, R. C.: Priming effect of benthic gastropod mucus on sedimentary organic matter remineralization, Limnol. Oceanogr., 61, 1640, https://doi.org/10.1002/lno.10325, 2016.

Hartgers, W. A., Damste, J. S. S., Requejo, A. G., Allan, J., Hayes, J. M., and De Leeuw, J. W.: Evidence for only minor contributions from bacteria sedimentary carbon, Nature, 369, 224-227, 1994.

Hartnett, H. E. and Devol, A. H.: Role of a strong oxygen-deficient zone in the preservation and degradation of organic matter: A carbon budget for the continental margins of northwest Mexico and Washington State, Geochim. Cosmochim. Ac., 67, 247-264, 2003.

Hartnett, H. E., Keil, R. G., Hedges, J. I., and Devol, A. H.: Influence of oxygen exposure time on organic carbon preservation in continental margin sediments, Nature, 391, 572-574, 1998.

Hayes, J. M., Popp, B. N., Takigiku, R., and Johnson, M. W.: An isotopic study of biogeochemical relationships between carbonates and organic carbon in the Greenhorn Formation, Geochim. Cosmochim. Ac., 53, 2961-2972, 1998.

Hedges, J. I. and Keil, R. G.: Sedimentary Organic-Matter Preservation - an Assessment and Speculative Synthesis, Mar. Chem., 49, 81-115, 1995.

Hedges, J. I., Eglinton, G., Hatcher, P. G., Kirchman, D. L., Arnosti, C., Derenne, S., Evershed, R. P., Kögel-Knabner, I., de Leeuw, J. W., Littke, R., Michaelis, W., and Rullkötter, J.: The molecularlyuncharacterized component of nonliving organic matter in natural environments, Org. Geochem. 31, 945-958, 2000.

Herman, P. M. J., Middelburg, J. J., Van de Koppel, J., and Heip, C. H. R.: Ecology of estuarine macrobenthos, Adv. Ecol. Res., 29, 195-240, 1999.

Hoer, D. R., Gibson P. J., Tommerdahl, J. P., Lindquist N. L., and Martens C. S.: Consumption of dissolved organic carbon by Caribbean reef sponges, Limnol. Oceanogr., https://doi.org/10.1002/lno.10634, 2018.
Hondeveld, B. J. M., Bak, R. P. M., and Van Duyl, F. C.: Bacterivory by heterotrophic nanoflagellates in marine sediments measured by uptake of fluorescently labelled bacteria, Mar. Ecol.-Prog. Ser., 89, 63-71, 1992.

Huguet, C., de Lange, G. J., Gustafsson, Ö, Middelburg, J. J., Sinninghe Damsté, J. S., and Schouten, S.: Selective preservation of soil organic matter in oxidized marine sediments (Madeira Abyssal Plain), Geochim. Cosmochim. Ac., 72, 6061-6068, https://doi.org/10.1016/j.gca.2008.09.021, 2008.

Huettel, M., Berg, P., and Kostka J. E.: Benthic exchange and biogeochemical cycling in permeable sediments, Ann. Rev. Mar. Sci., 6, 23-51, 2014.

Jessen, G. L., Lichtschlag, A., Ramette, A., Pantoja, S., Rossel, P. E., Schubert, C. J., Struck, U., and Boetius, A.: Hypoxia causes preservation of labile organic matter and changes microbial community composition (Black Sea shelf), Sci. Adv., 3, e1601897, https://doi.org/10.1126/sciadv.1601897, 2017.

Jørgensen, B. B.: Sulphur cycle of a coastal marine sediment (Limfjorden, Denmark), Limnol. Oceanogr., 22, 814-832, 1977

Jørgensen, B. B.: A comparison of methods for the quantification of bacterial sulfate reduction in coastal marine sediments, II. Calculation from mathematical models, Geomicrobiol. J., 1, 29-47, 1979.

Jørgensen, B. B.: Mineralization of organic matter in the sea bed the role of sulphate reduction, Nature, 296, 643-645, 1982.

Jørgensen, B. B.: Bacteria and marine biogeochemistry, edited by: Shulz, H. D. and Zabel, M., Springer-Verlag Berlin Heidelberg, Marine Geochemistry, 169-206, 2006.

Jumars, P. A., Penry, D. L., Baross, J. A., Perry, M. J., and Frost, B. W.: Closing the microbial loop: dissolved organic carbon pathway to heterotrophic bacteria from incomplete ingestion, digestion and absorption in animals, Deep-Sea Res. Pt. A, 36, 483495, 1989.

Kemp, P. F.: Bacterivory by benthic ciliates: significance as a carbon source and impact on sediment bacteria, Mar. Ecol.-Prog. Ser., 49, 163-169, 1988.

Kemp, P. F.: The fate of benthic bacterial production, Rev. Aquat. Sci., 2, 109-124, 1990 .

Koho, K. A., Nierop, K. G. J., Moodley, L., Middelburg, J. J., Pozzato, L., Soetaert, K., van der Plicht, J., and Reichart, G.J.: Microbial bioavailability regulates organic matter preservation in marine sediments, Biogeosciences, 10, 1131-1141, https://doi.org/10.5194/bg-10-1131-2013, 2013.

Keil, R. G. and Fogel, M. L.: Reworking of amino acid in marine sediments: stable carbon isotopic composition of amino acids in sediments along the Washington coast, Limnol. Oceanogr., 46, 14-23, 2001.

Keil, R. G., Tsamakis, E. and Hedges, J. I.: Early diagenesis of particulate animo acids in marine systems, in: Perspectives in Amino Acid and Protein Geochemistry, edited by: Goodfriend, G. A., Collins, M. J., Fogel, M. L., Macko, S. E., and Wehmiller, J. F., Oxford University Press, 2000.

Kristensen, E., Ahmed, S. I., and Devol, A. H.: Aerobic and anaerobic decomposition of organic matter in marine sediment: Which is fastest?, Limnol. Oceanogr., 40, 1430-1437, 1995.

Kristensen, E., Penha-Lopes, G., Delefosse, M., Valdemarsne T., Quintana, C. O., and Banta, G. T.: What is bioturbation? The need for a precise definition for fauna 
in aquatic sciences, Mar. Ecol.-Prog. Ser., 46, 285-302, https://doi.org/10.3354/meps09506, 2012.

Krumins, J. A., van Oevelen, D., Bezemer, T. M., De Deyn, G. B., Hol, W. H. G., van Donk, E., de Boer, W., de Ruiter, P. C., Middelburg, J. J., Monroy, F., Soetaert, K., Thebault, E., van de Koppel, J., van Veen, J. A., Viketoft, M., and van der Putten, W. H.: Soil and Freshwater and Marine Sediment Food Webs: Their Structure and Function, Bioscience, 63, 35-42, https://doi.org/10.1525/bio.2013.63.1.8, 2013.

Lee, C., Wakeham, S. G., and Hedges, J. I.: Composition and flux of particulate amino acids and chloropigments in equatorial Pacific seawater and sediments, Deep-Sea Res. Pt. I, 47, 1535-1568, 2000.

Lenton, T. and Watson, A.: Revolutions that made the earth, Oxford University Press, 2011.

Levin, L. A.: Oxygen minimum zone benthos: Adaptation and community response to hypoxia, Ann. Rev. Oceanogr. Mar. Biol., 41, 1-45, 2003.

Levin, L. A., Ekau, W., Gooday, A. J., Jorissen, F., Middelburg, J. J., Naqvi, S. W. A., Neira, C., Rabalais, N. N., and Zhang, J.: Effects of natural and human-induced hypoxia on coastal benthos, Biogeosciences, 6, 2063-2098, https://doi.org/10.5194/bg6-2063-2009, 2009.

Lichtner, P. C.: Continuum representation of multi-componentmultiphase reactive transport, Rev. Mineral., 34, 1-82, 1996.

Lipsewers, Y. A., Hopmans, E. C., Sinnighe Damste, J. S., and Villanueva, L.: Potential recycling of thaumarchaeotal lipids by DPANN archaea in seasonally hypoxic surface marine sediments, Org. Geochem., in press, https://doi.org/10.1016/j.orggeochem.2017.12.007, 2018.

Lomstein, B. A., Jørgensen, B. B., Schubert, C. J., and Niggemann, J.: Amino acid biogeo- and stereochemistry in coastal Chilean sediments, Geochim. Cosmochim. Ac., 70, 2970-2989, https://doi.org/10.1016/j.gca.2006.03.015, 2006.

Lomstein, B. A., Langerhuus, A. T., D’Hondt, S., Jørgensen, B. B., and Spivack, A.: Endospore abundance, microbial growth and necromass turnover in deep subseafloor sediment, Nature, 484, 101-104, 2012.

Meysman, F. J. R., Middelburg, J. J., Herman, P. M. J., and Heip, C. H. R.: Reactive transport in surface sediments: 2. Media: an object-oriented problem-solving environment for early diagenesis, Comput. Geosci., 29, 301-318, 2003.

Meysman, F. J. R., Middelburg, J. J., and Heip, C. H. R.: Bioturbation: a fresh look at Darwin's last idea, Trends Ecol. Evol., 21, 688-695, 2006.

Meysman, F. J. R., Boudreau, B. P., and Middelburg, J. J.: Relations between local, nonlocal, discrete and continuous models of bioturbation, J. Mar. Res., 61, 391-410, 2003.

Meysman, F. J. R., Boudreau, B. P., and Middelburg, J. J.: When and why does bioturbation lead to diffusive mixing?, J. Mar. Res., 68, 881-920, 2010.

Middelburg, J. J.: A simple rate model for organic-matter decomposition in marine-sediments, Geochim. Cosmochim. Ac., 53, 1577-1581, 1989.

Middelburg, J. J.: Chemoautotrophy in the ocean, Geophys. Res. Lett., 38, L24604, https://doi.org/10.1029/2011GL049725, 2011.

Middelburg, J. J.: Stable isotopes dissect aquatic food webs from the top to the bottom, Biogeosciences, 11, 2357-2371, https://doi.org/10.5194/bg-11-2357-2014, 2014.
Middelburg, J. J. and Levin, L. A.: Coastal hypoxia and sediment biogeochemistry, Biogeosciences, 6, 1273-1293, https://doi.org/10.5194/bg-6-1273-2009, 2009.

Middelburg, J. J., Vlug, T., and Van der Nat, F.: Organic matter mineralization in marine systems, Glob. Planet. Change, 8, 47$58,1993$.

Middelburg, J. J., Soetaert, K., Herman, P. M. J., and Heip, C. H. R.: Denitrification in marine sediments: A model study, Global Biogeochem. Cy., 10, 661-673, 1996.

Middelburg, J. J., Nieuwenhuize, J., and van Breugel, P.: Black carbon in marine sediments, Mar. Chem., 65, 245-252, 1999.

Middelburg, J. J., Barranguet, C., Boschker, H. T. S., Herman, P. M. J., Moens, T., and Heip, C. H. R.: The fate of intertidal microphytobenthos carbon: An in situ C-13-labeling study, Limnol. Oceanogr., 45, 1224-1234, 2000.

Moodley, L., Middelburg, J. J., Boschker, H. T. S., Duineveld, G. C. A., Pel, R., Herman, P. M. J., and Heip, C. H. R.: Bacteria and Foraminifera: key players in a short-term deep-sea benthic response to phytodetritus, Mar. Ecol.-Prog. Ser., 236, 23-29, https://doi.org/10.3354/meps236023, 2002.

Moodley, L., Middelburg, J. J., Soetaert, K., Boschker, H. T. S., Herman, P. M. J., and Heip, C. H. R.: Similar rapid response to phytodetritus deposition in shallow and deep-sea sediments, J. Mar. Res., 63, 457-469, https://doi.org/10.1357/0022240053693662, 2005a.

Moodley, L., Middelburg, J. J., Herman, P. M. J., Soetaert, K., and de Lange, G. J.: Oxygenation and organic-matter preservation in marine sediments: Direct experimental evidence from ancient organic carbon-rich deposits, Geology, 33, 889-892, 2005b.

Müller, P. J.: C / N ratios in Pacific deep-sea sediments: effect of inorganic ammonium and organic nitrogen compounds sorbed by clays, Geochim. Cosmochim. Ac., 41, 549-553, 1997.

Nierop, K. G. J., Reichart, G.-J., Veld, H., and Sinninghe Damsté, J. S.: The influence of oxygen exposure time on the composition of macromolecular organic matter as revealed by surface sediments on the Murray Ridge (Arabian Sea), Geochim. Cosmochim. Ac., 206, 40-56, https://doi.org/10.1016/j.gca.2017.02.032, 2017.

Nomaki, H., Heinz, T., Nakatsuka, T., Shimanaga, M., and Kitazato, H.: Species-specific ingestion of organic carbon by deep-sea benthic foraminifera and meiobenthos: In situ tracer experiments, Limnol. Oceanogr., 50, 134-146, 2005.

Oakes, J. M., Eyre, B. D., and Middelburg, J. J.: Transformation and fate of microphytobenthos carbon in subtropical shallow subtidal sands: A C-13-labeling study, Limnol. Oceanogr., 57, 18461856, https://doi.org/10.4319/lo.2012.57.6.1846, 2012.

Pimm, S. L., Lawton, J. H., and Cohen, J. E.: Food web patterns and their consequences, Nature, 350, 669-674, 1991.

Pomeroy, L.: The ocean's food web, a changing paradigm, Bioscience, 24, 499-504, 1974.

Rabouille, C. and Gaillard, J.-F.: Towards the EDGE: early diagenetic global explanation, A model depicting the early diagenesis of organic matter, $\mathrm{O}_{2}, \mathrm{NO}_{3}, \mathrm{Mn}$, and $\mathrm{PO}_{4}$, Geochim. Cosmochim. Ac., 55, 2511-2525, 1991.

Raghoebarsing, A. A., Pol, A., van de Pas-Schoonen, K. T., Smolders, A. J. P., Ettwig, K. F., Rijpstra, W. I. C., Schouten, S., Sinninghe Damsté, J. S., Op den Camp, H. J. M., Jetten, M. S. M., and Strous, M.: A microbial consortium couples anaerobic methane oxidation to denitrification, Nature, 440, 918-921, 2006. 
Rex, M. A., Etter, R. J., Morris, J. S., Crouse, J., McClain, C. R., Johnson, N. A., Stuart, C. T., Deming, J. W., Thies, R., and Avery, R.: Global bathymetric patterns of standing stock and body size in the deep-sea benthos, Mar. Ecol.-Prog. Ser., 317, 1-8, 2006.

Rhoads, D. C. and Morse, J. W.: Evolutionary and ecological significance of oxygen-deficient marine basins, Lethaia, 4, 413-428, 1971.

Rhoads, D. C.: Organism-sediment relations on the muddy sea floor, Oceanogr. Mar. Biol. Ann. Rev., 12, 263-300, 1974.

Rice, D. L.: Early diagenesis in bioadvective sediments: relationships between the diagenesis of beryllium-7, sediment reworking rates, and the abundance of conveyor-belt deposit-feeders, J. Mar. Res., 44, 149-184, 1986.

Rice, D. L. and Rhoads, D. C.: Early diagenesis of organic matter and the nutritional value of sediment, in: Ecology of Marine Deposit Feeders, edited by: Lopez, G., Taghon, G., and Levinton, J., Springer, Berlin, 309-317, 1989.

Rix, L., De Goeij, J. M., Mueller, C. E. , Struck, U., Middelburg, J. J., Van Duyl, F. C., Al-Horani, F. A., Wild, C., Naumann, M. S., and Van Oevelen, D.: Coral mucus fuels the sponge loop in warm- and cold-water coral reef ecosystems, Sci. Rep., 6, 18715, https://doi.org/10.1038/srep18715, 2016.

Roberts, J. M., Wheeler, A. J., and Freiwald, A.: Reefs of the deep, The biology and geology of cold-water coral ecosystems, Science, 312, 543-547, 2006.

Rossi, S., Bramanti, L., Gori, A., and Covadonga, O.: An overview of the animal forest of the world, in: Marine Animal Forest, Rossi, S., Springer, 1-25, 2017.

Schouten, S., Middelburg, J. J., Hopmans, E. C., and Sinninghe Damsté, J. S.: Fossilization and degradation of intact polar lipids in deep subsurface sediments: A theoretical approach, Geochim. Cosmochim. Ac., 74, 3806-3814, 2010.

Sinninghe Damsté, J. S., Rijpstra, W. I. C., and Reichart, G. J.: The influence of oxic degradation on the sedimentary biomarker record, II. Evidence from Arabian Sea sediments, Geochim. Cosmochim. Ac., 66, 2737-2754, 2002.

Soetaert, K., Herman, P. M. J., and Middelburg, J. J.: A model of early diagenetic processes from the shelf to abyssal depths, Geochim. Cosmochim. Ac., 60, 1019-1040, 1996.

Soetaert, K., Middelburg, J. J., Herman, P. M. J., and Buis, K.: On the coupling of benthic and pelagic biogeochemical models, Earth-Sci. Rev., 51, 173-201, 2000.

Soetaert, K., Mohn, C., Rengstorf, A., Grehan, A., and van Oevelen, D.: Ecosystem engineering creates a direct nutritional link between 600-m deep cold-water coral mounds and surface productivity, Sci. Rep., 6, 35057, https://doi.org/10.1038/srep35057, 2016.

Steenbergh, A. K., Bodelier, P. L. E., Heidal, M., Slomp, C. P., and Laanbroek, H. J.: Does microbial stoichiometry modulate eutrophication of aquatic ecosystems?, Environ. Microbiol., 15, 1572-1579, 2013.

Sterner, R. W. and Elser, J. J.: Ecological Stoichiometry, Princeton University Press, 439 pp., 2002.

Strous, M. and Jetten, M. S. M.: Anaerobic oxidation of methane and ammonium, Annu. Rev. Microbiol., 58, 99-117, 2004.

Sun, M. Y., Aller, R. C., Lee, C., and Wakeham, S. G.: Enhanced degradation of algal lipids by benthic macrofaunal activity: effect of Yoldia limatula, J. Mar. Res., 57, 775-804, 1999.
Sweetman, A. K. and Witte, U.: Response of an abyssal macrofaunal community to a phytodetrital pulse, Mar. Ecol.-Prog. Ser., 355, 73-84, https://doi.org/10.3354/meps07240, 2008.

Takano, Y., Chikaraishi, Y., Ogawa, N.O., Nomaki, H., Morono, Y., Inagaki, F., Kitazato, H., Hinrichs, K.-U., and Ohkouchi, N.: Sedimentary membrane lipids recycled by deep-sea benthic archaea, Nat. Geosci., 3, 858-861, https://doi.org/10.1038/ngeo983, 2010.

Tegelaar, E. W., de Leeuw, J. W., Derenne, S., and Largeau, C.: A reappraisal of kerogen formation, Geochim. Cosmochim. Ac., 53, 3103-3106, https://doi.org/10.1016/0016-7037(89)90191-9, 1989.

Thomas, C. J. and Blair, N. E.: Transport and digestive alteration of uniformly 13C-labelled diatoms in mudflat sediments, J. Mar. Res., 60, 517-535, 2002.

Van Cappellen, P. and Wang, Y. F.: Cycling of iron and manganese in surface sediments: A general theory for the coupled transport and reaction of carbon, oxygen, nitrogen, sulfur, iron, and manganese, Am. J. Sci., 296, 197-243, https://doi.org/10.2475/ajs.296.3.197, 1996.

Vandewiele, S., Cowie, G., Soetaert, K., and Middelburg, J. J.: Amino acid biogeochemistry and organic matter degradation state across the Pakistan margin oxygen minimum zone, DeepSea Res. Pt. II, 56, 318-334, 2009.

Vanni, M. J. and McIntyre, P. B.: Predicting nutrient excretion of aquatic animals with metabolic ecology and ecological stoichiometry: a global synthesis, Ecology, 97, 3460-3471, https://doi.org/10.1002/ecy.1582, 2016.

Vanni, M. J.: Nutrient cycling by animals in freshwater ecosystems, Annu. Rev. Ecol. Syst., 33, 341-370, 2002.

Van Nugteren, P., Moodley, L., Brummer, G.-J., Heip, C. H. R., Herman, P. M. J., and Middelburg, J. J.: Seafloor ecosystem functioning: the importance of organic matter priming, Mar. Bio.,156, 2277-2287, 2009a.

van Nugteren, P., Herman, P. M., Moodley, L., Middelburg, J. J., and Vos, M.: Spatial distribution of detrital resources determines the outcome of competition between bacteria and a facultative detritivorous worm, Limnol. Oceanogr., 54, 1413-1419, $2009 \mathrm{~b}$.

van Oevelen, D., Moodley, L., Soetaert, K., and Middelburg, J. J.: The trophic significance of bacterial carbon in a marine intertidal sediment: Results of an in situ stable isotope labeling study, Limnol. Oceanogr., 51, 2349-2359, 2006.

van Oevelen, D., Van den Meersche, K., Meysman, F. J. R., Soetaert, K., Middelburg, J. J., and Vezina, A. F.: Quantifying Food Web Flows Using Linear Inverse Models, Ecosystems, 13, 32-45, https://doi.org/10.1007/s10021-009-9297-6, 2010.

Veuger, B., Eyre, B. D., Maher, D., and Middelburg, J. J.: Nitrogen incorporation and retention by bacteria, algae, and fauna in a subtropical intertidal sediment: An in situ N-15-labeling study, Limnol. Oceanogr., 52, 1930-1942, https://doi.org/10.4319/lo.2007.52.5.1930, 2007.

Veuger, B., van Oevelen, D., and Middelburg, J. J.: Fate of microbial nitrogen, carbon, hydrolysable amino acids, monosaccharides, and fatty acids in sediment, Geochim. Cosmochim. Ac., 83, 217-233, 2012.

Volkenborn, N., Polerecky, L., Wethey, D. S., and Woodin, S. A.: Oscillatory porewater bioadvection in marine sediments induced by hydraulic activities of Arenicola marina, Limnol. Oceanogr., 55, 1231-1247, 2010. 
Volkenborn, N., Woodin, S. A., Wethey, D. S., and Polerecky, L.: Bioirrigation in marine sediments, Reference Module in Earth Systems and Environmental Sciences, Elsevier, $10 \mathrm{pp}$., https://doi.org/10.1016/B978-0-12-409548-9.09525-7, 2016

Wakeham, S. G., Lee, C., Hedges, J. I., Hernes, P. J., and Peterson, M. L.: Molecular indicators of diagenetic status in marine organic matter, Geochim. Cosmochim. Ac., 61, 5363-5369, 1997.

Westrich, J. T. and Berner, R. A.: The role of sedimentary organic matter in bacterial sulphate reduction - the G model tested, Limnol. Oceanogr., 29, 236-249, 1984.

Witte, U., Wenzhofer, F., Sommer, S., Boetius, A., Heinz, P., Aberle, N., Sand, M., Cremer, A., Abraham, W. R., Jorgensen, B. B., and Pfannkuche, O.: In situ experimental evidence of the fate of a phytodetritus pulse at the abyssal sea floor, Nature, 424, 763766, https://doi.org/10.1038/nature01799, 2003.

Woulds, C., Andersson, J. H., Cowie, G. L., Middelburg, J. J., and Levin, L. A.: The short-term fate of organic carbon in marine sediments: Comparing the Pakistan margin to other regions, Deep-Sea Res. Pt. I, 56, 393-402, https://doi.org/10.1016/j.dsr2.2008.10.008, 2009.
Woulds, C., Cowie, G. L., Levin, L. A., Andersson, J. H., Middelburg, J. J., Vandewiele, S., Lamont, P. A., Larkin, K. E., Gooday, A. J., Schumacher, S., Whitcraft, C., Jeffreys, R. M., and Schwartz, M.: Oxygen as a control on seafloor biological communities and their roles in sedimentary carbon cycling, Limnol. Oceanogr., 52, 1698-1709, https://doi.org/10.4319/lo.2007.52.4.1698, 2007.

Woulds, C., Middelburg, J. J., and Cowie, G. L.: Alteration of organic matter during infaunal polychaete gut passage and links to sediment organic geochemistry, Part I: Amino acids, Geochim. Cosmochim. Ac., 77, 396-414, 2012.

Woulds, C., Middelburg, J. J., and Cowie, G. L.: Alteration of organic matter during infaunal polychaete gut passage and links to sediment organic geochemistry, Part II: Fatty acids and aldoses, Geochim. Cosmochim. Ac., 136, 38-59, 2014.

Woulds, C., Bouillon, S., Cowie, G. L., Drake, E., Middelburg, J. J., and Witte, U.: Patterns of carbon processing at the seafloor: the role of faunal and microbial communities in moderating carbon flows, Biogeosciences, 13, 4343-4357, https://doi.org/10.5194/bg-13-4343-2016, 2016. 